\title{
Molecular Recognition of Carbohydrates with Acyclic Pyridine-Based Receptors
}

\author{
Monika Mazik, Wolfgang Radunz, and Roland Boese
}

$1 \quad{ }^{1} \mathrm{H}$ and ${ }^{13} \mathrm{C}$ NMR spectra of compounds $2-4,6,8,9,10,11,14$.

FIGURE 1a/1b. ${ }^{1} \mathrm{H}$ NMR $(500 \mathrm{MHz})$ spectrum of compound 2 in $\mathrm{CDCl}_{3}$. FIGURE 2. ${ }^{13} \mathrm{C}$ NMR $(125 \mathrm{MHz})$ spectrum of compound 2 in $\mathrm{CDCl}_{3}$.

FIGURE 3a/3b. ${ }^{1} \mathrm{H}$ NMR $(500 \mathrm{MHz})$ spectrum of compound 3 in $\mathrm{CDCl}_{3}$. FIGURE 4. ${ }^{13} \mathrm{C}$ NMR $(125 \mathrm{MHz})$ spectrum of compound 3 in $\mathrm{CDCl}_{3}$.

FIGURE 5a/5b. ${ }^{1} \mathrm{H}$ NMR $(500 \mathrm{MHz})$ spectrum of compound 4 in $\mathrm{CDCl}_{3}$. FIGURE 6. ${ }^{13} \mathrm{C} \mathrm{NMR}(125 \mathrm{MHz})$ spectrum of compound 4 in $\mathrm{CDCl}_{3}$.

FIGURE 7a/7b. ${ }^{1} \mathrm{H}$ NMR $(500 \mathrm{MHz})$ spectrum of compound 6 in $\mathrm{CDCl}_{3}$. FIGURE 8. ${ }^{13} \mathrm{C}$ NMR $(125 \mathrm{MHz})$ spectrum of compound 6 in $\mathrm{CDCl}_{3}$.

FIGURE 9a/9b. ${ }^{1} \mathrm{H}$ NMR (500 MHz) spectrum of compound 8 in $\mathrm{CDCl}_{3}$. FIGURE 10. ${ }^{13} \mathrm{C}$ NMR (125 MHz) spectrum of compound 8 in $\mathrm{CDCl}_{3}$.

FIGURE 11. ${ }^{1} \mathrm{H}$ NMR $(500 \mathrm{MHz})$ spectrum of compound 9 in $\mathrm{CDCl}_{3}$. FIGURE 12. ${ }^{13} \mathrm{C}$ NMR (125 MHz) spectrum of compound 9 in $\mathrm{CDCl}_{3}$.

FIGURE 13. ${ }^{1} \mathrm{H}$ NMR $(500 \mathrm{MHz})$ spectrum of compound 10 in $\mathrm{CDCl}_{3}$. FIGURE 14. ${ }^{13} \mathrm{C}$ NMR (125 MHz) spectrum of compound 10 in $\mathrm{CDCl}_{3}$.

FIGURE 15. ${ }^{1} \mathrm{H}$ NMR $(500 \mathrm{MHz})$ spectrum of compound 11 in $\mathrm{CDCl}_{3}$.

FIGURE 16. ${ }^{13} \mathrm{C}$ NMR (125 MHz) spectrum of compound 11 in $\mathrm{CDCl}_{3}$.

FIGURE 17a/17b. ${ }^{1} \mathrm{H}$ NMR $(500 \mathrm{MHz})$ spectrum of compound 14 in $\mathrm{CDCl}_{3}$.

FIGURE 18. ${ }^{13} \mathrm{C}$ NMR (125 MHz) spectrum of compound 14 in $\mathrm{CDCl}_{3}$.

$2 \quad{ }^{1}$ H NMR Titration: Titration of receptor 11 with $\beta$-glucopyranoside 16

FIGURE 19a/19b. Titration of receptor 11 with octyl $\beta$-D-glucopyranoside (16).

\section{Mole ratio method}

FIGURE 20a/20b. Mole ratio plot. Complexation of 3 with $\alpha$-glucopyranoside 17. 

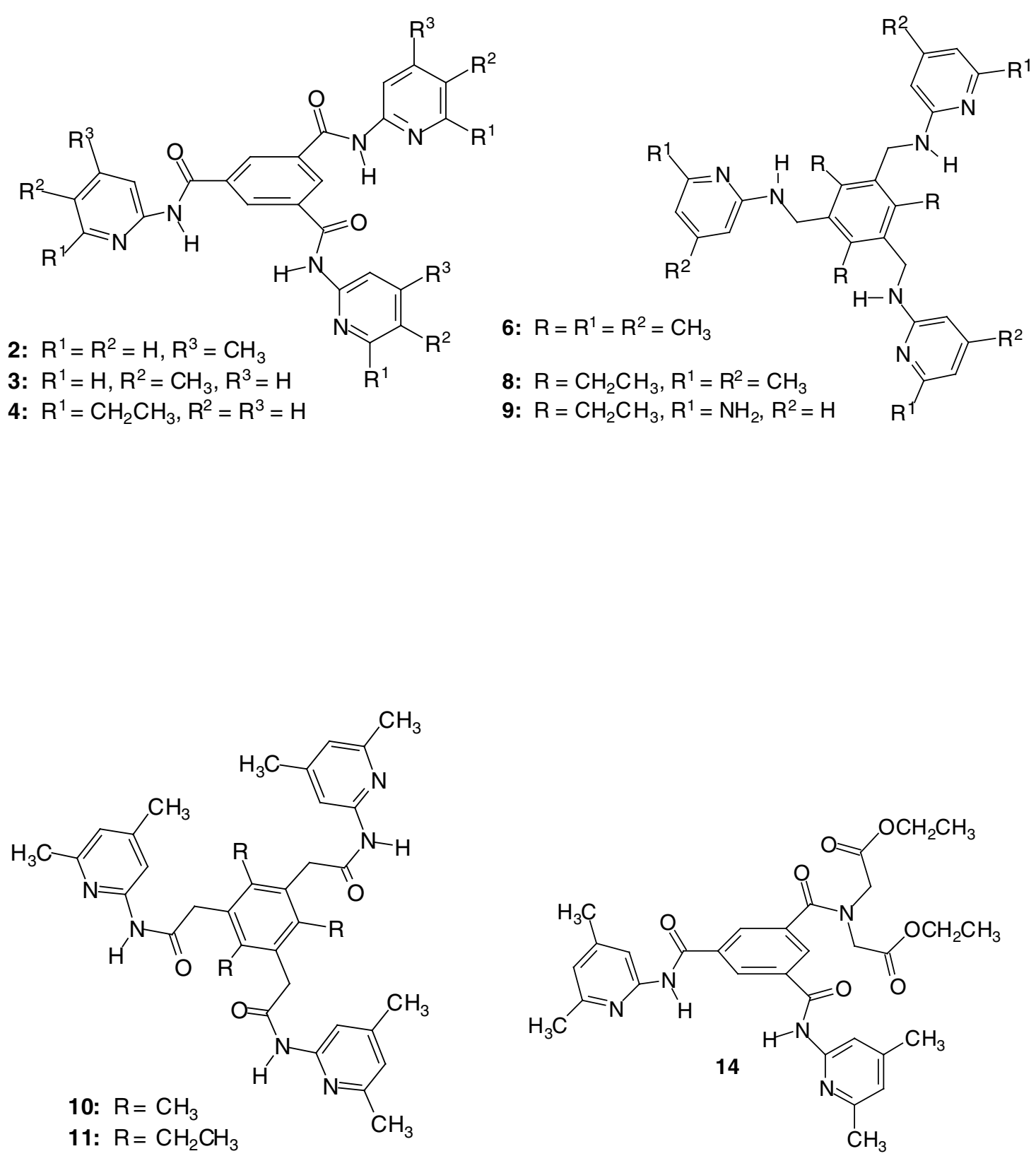

6: $\mathrm{R}=\mathrm{R}^{1}=\mathrm{R}^{2}=\mathrm{CH}_{3}$

8: $\mathrm{R}=\mathrm{CH}_{2} \mathrm{CH}_{3}, \mathrm{R}^{1}=\mathrm{R}^{2}=\mathrm{CH}_{3}$

9: $\mathrm{R}=\mathrm{CH}_{2} \mathrm{CH}_{3}, \mathrm{R}^{1}=\mathrm{NH}_{2}, \mathrm{R}^{2}=\mathrm{H}$<smiles>CCOC(=O)CN(CC(=O)OCC)C(=O)c1cc(C(=O)Nc2cc(C)cc(C)n2)cc(C(=O)Nc2cc(C)cc(C)n2)c1</smiles> 
$1 \quad{ }^{1} \mathrm{H}$ and ${ }^{13} \mathrm{C}$ NMR spectra of compounds $2-4,6,8,9,10,11,14$.

$N, N^{\prime}, N^{\prime \prime}$-Tris-(4-methylpyridin-2-yl)benzene-1,3,5-tricarbonamide (2)
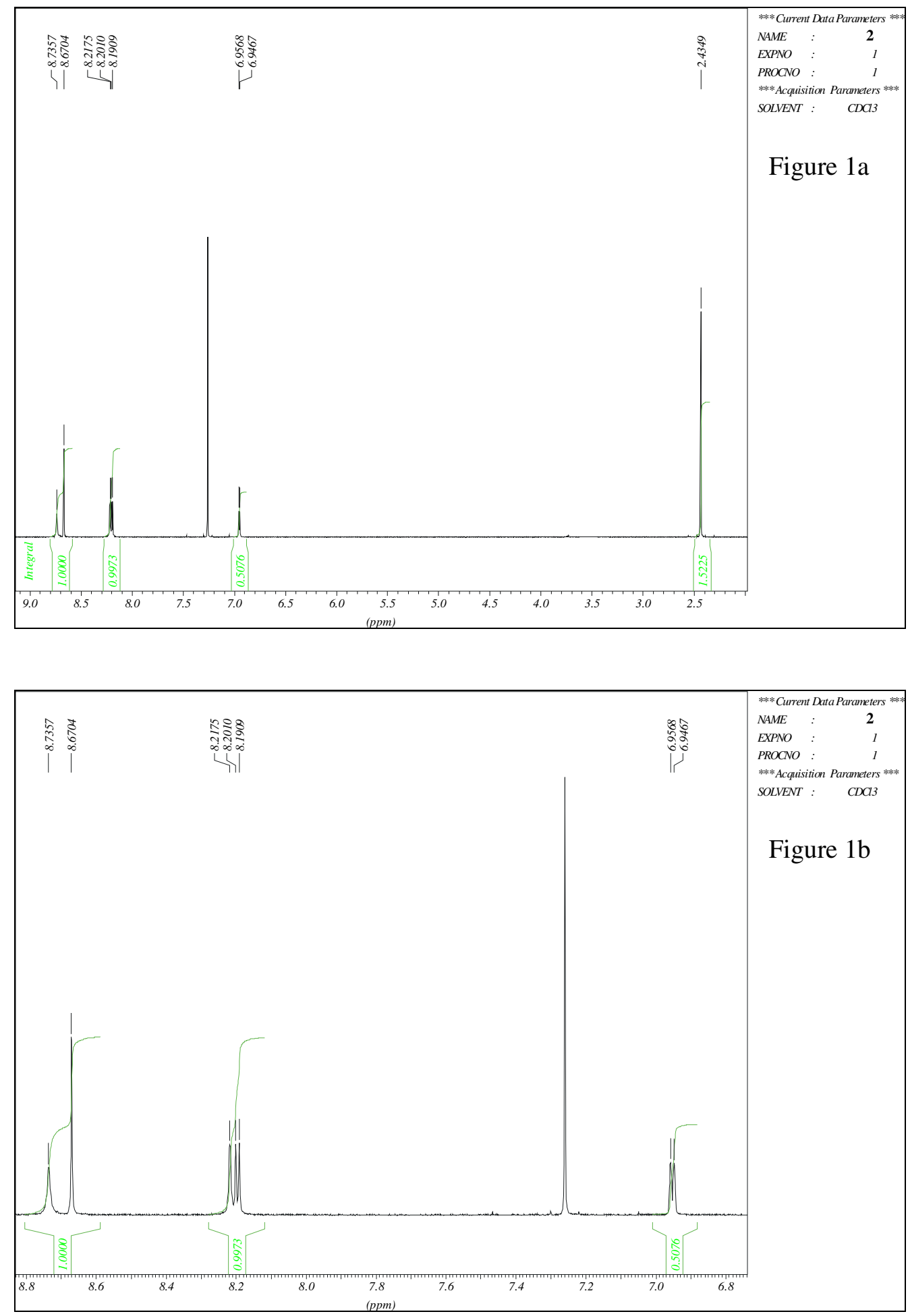


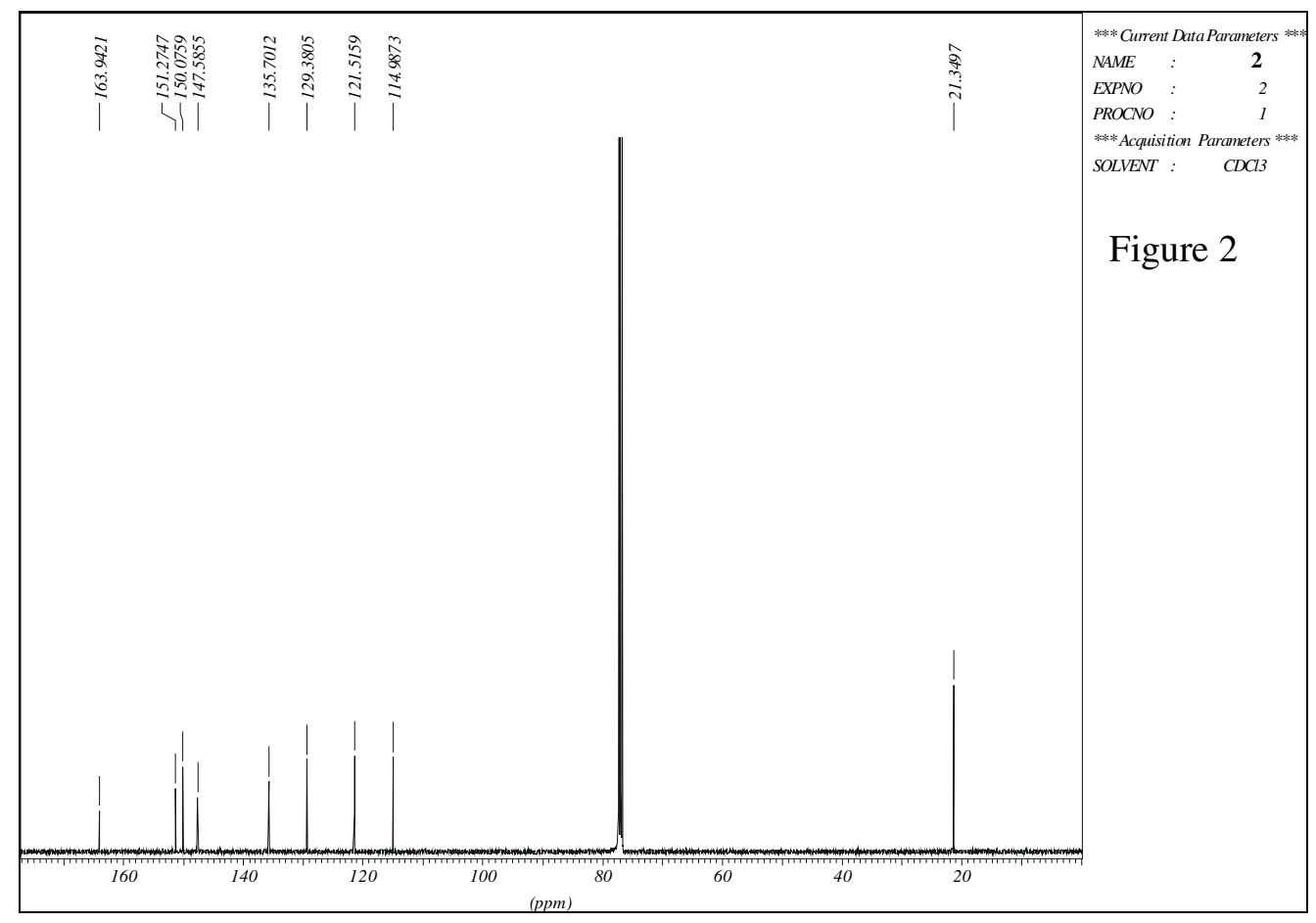

$N, N^{\prime}, N^{\prime \prime}$-Tris-(5-methyl-pyridin-2-yl)benzene-1,3,5-tricarbonamide (3)

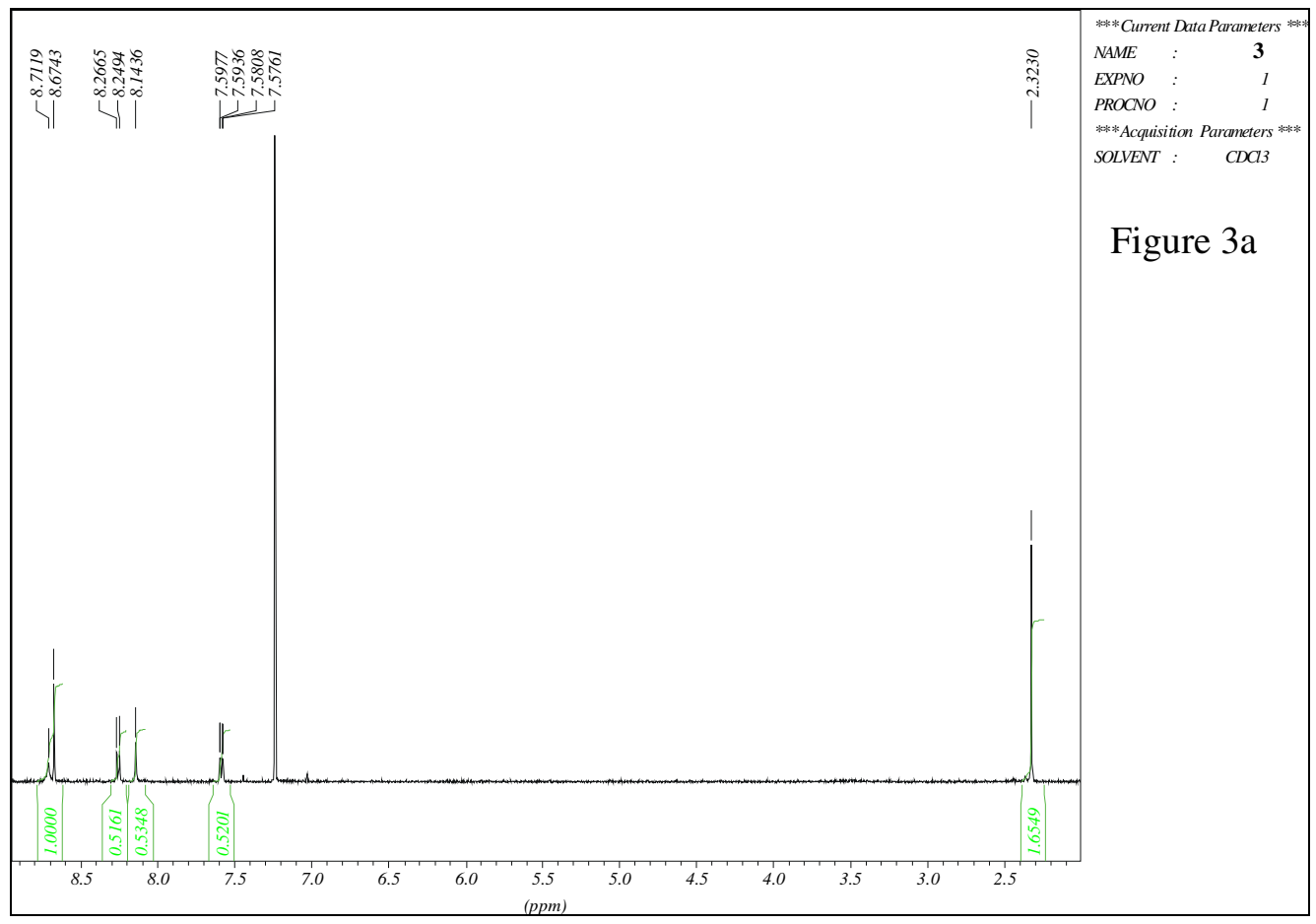



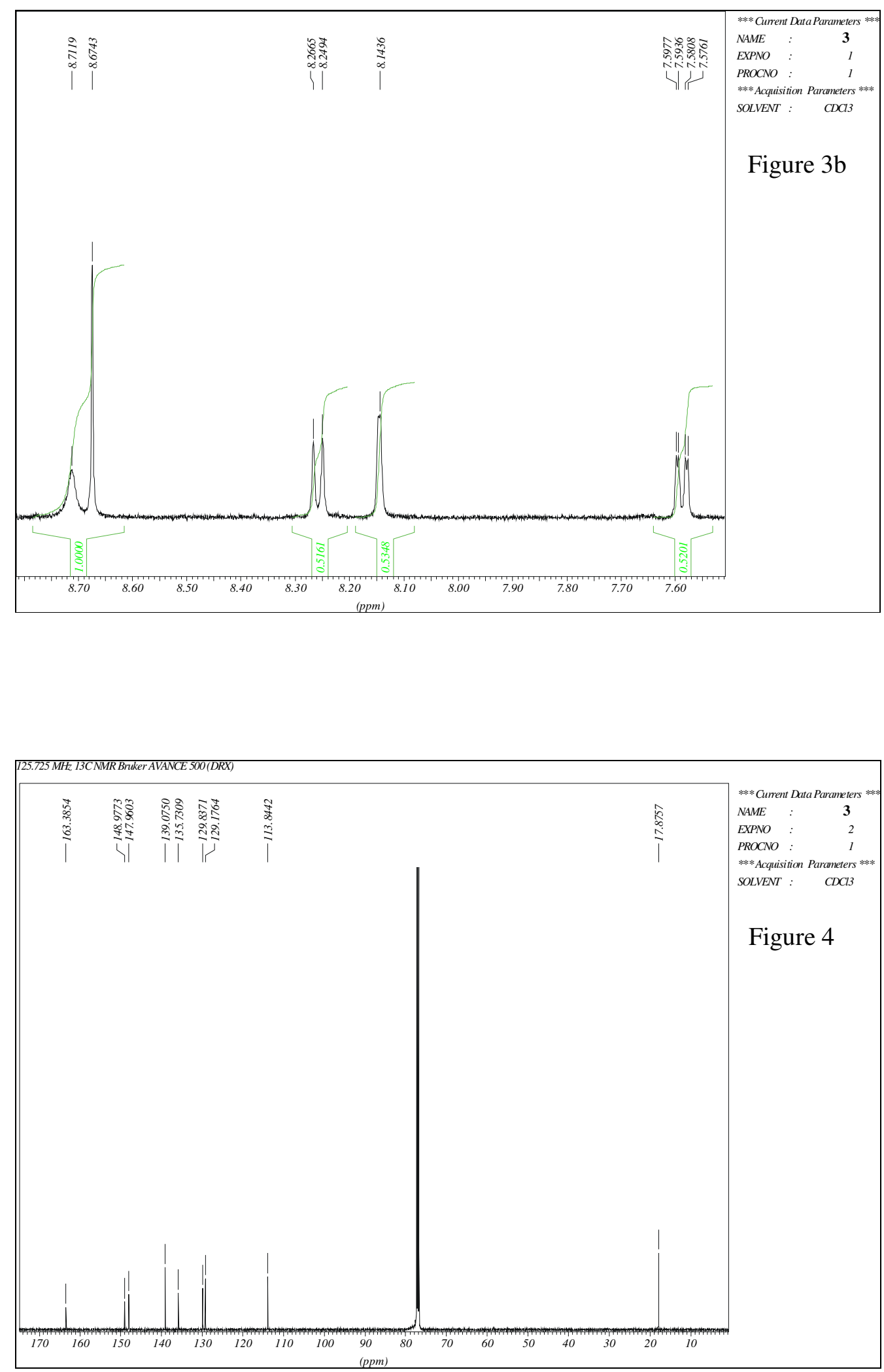
$N, N^{\prime}, N^{\prime \prime}$-Tris-(6-ethylpyridin-2-yl)benzene-1,3,5-tricarbonamide (4)
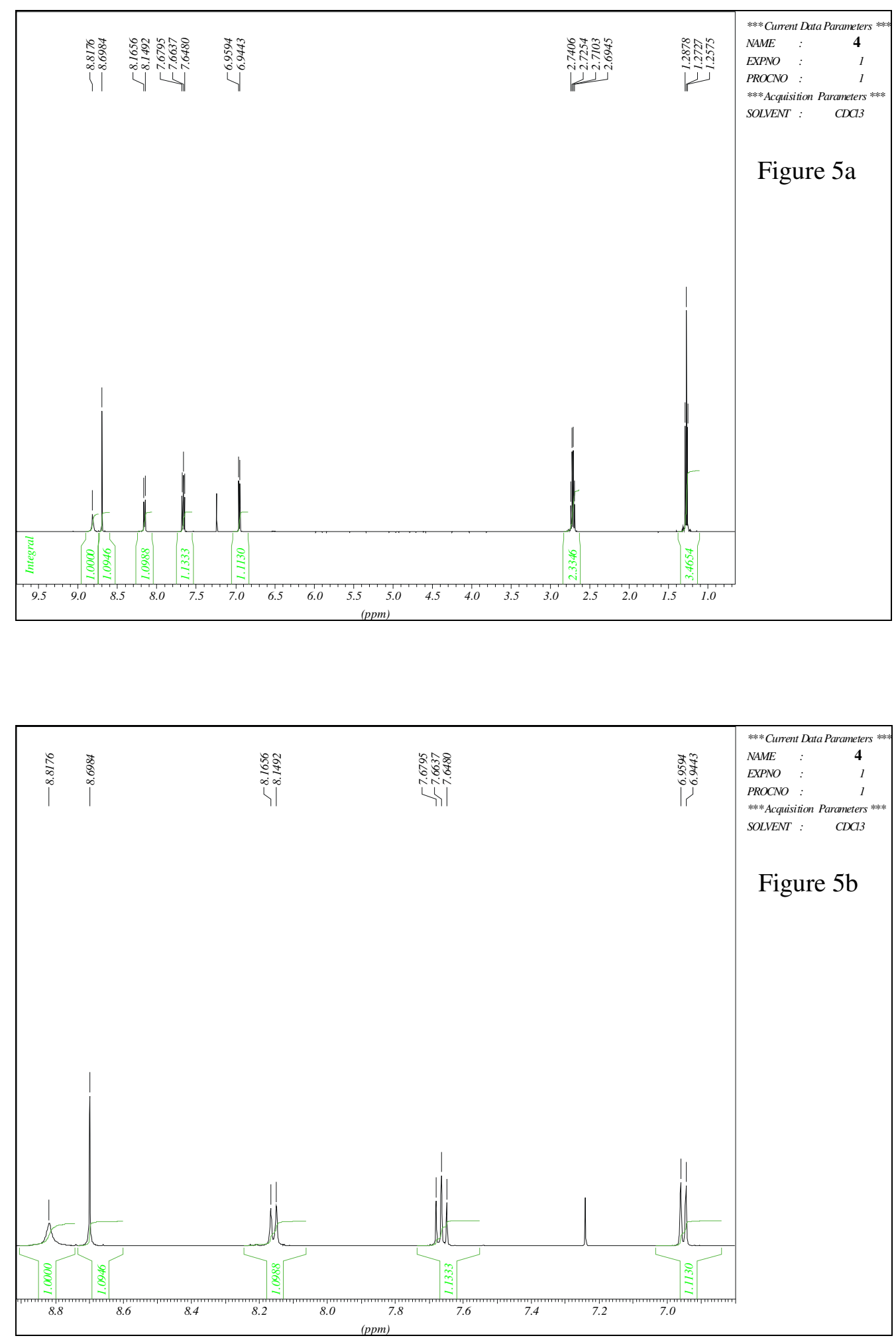


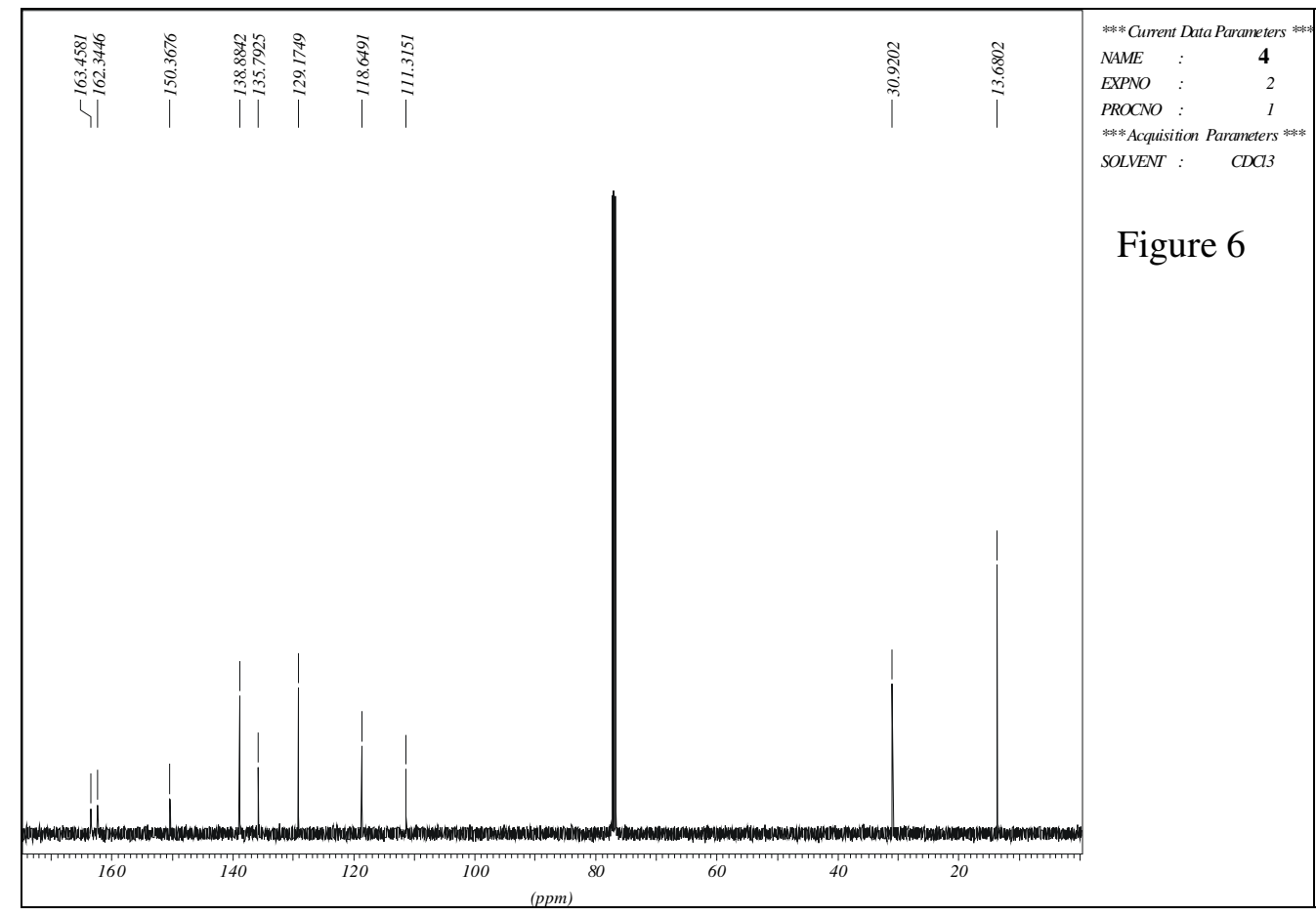

1,3,5-Tris[(4,6-dimethyl-pyridin-2-yl)aminomethyl]-2,4,6-trimethyl-benzene (6)

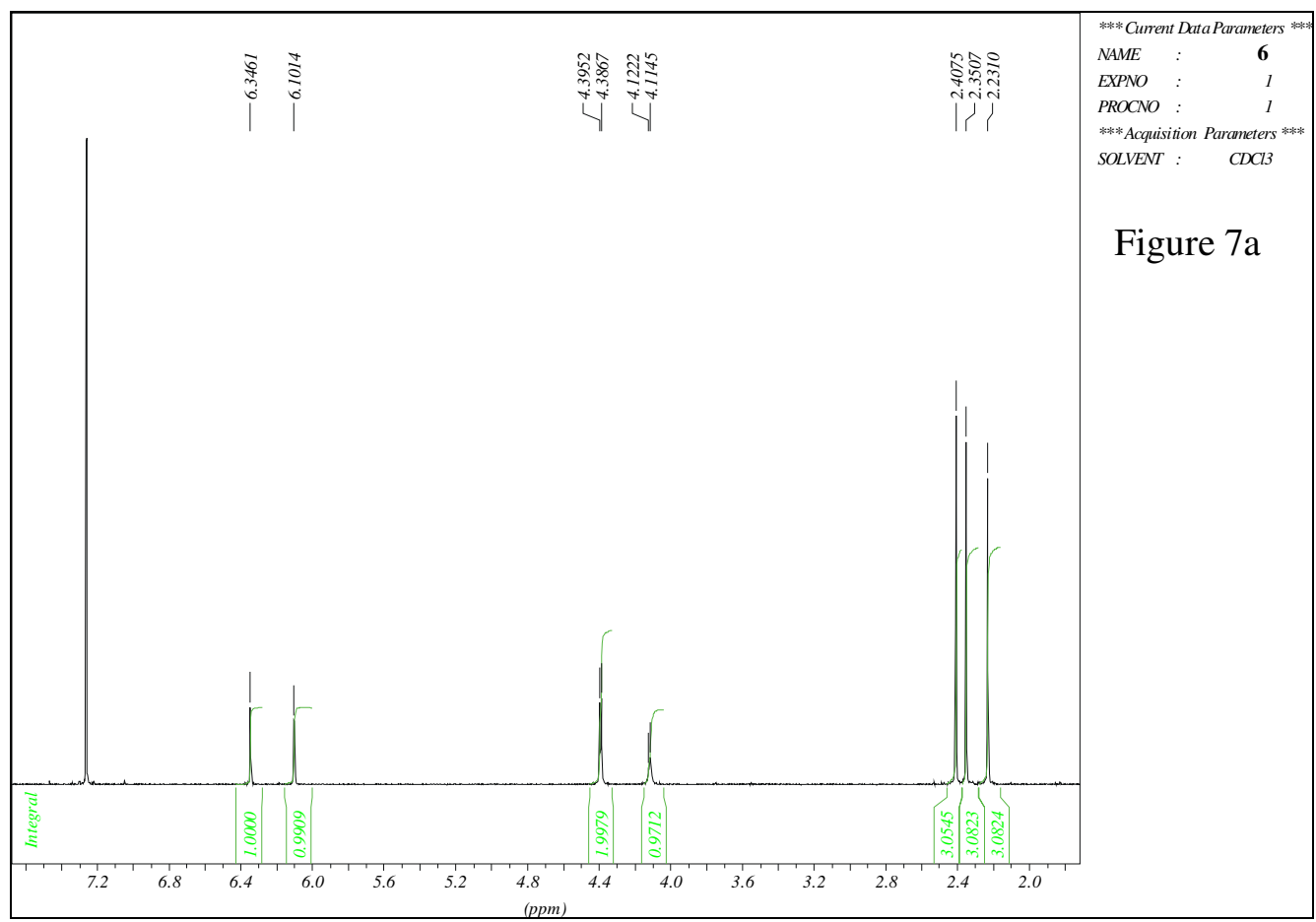



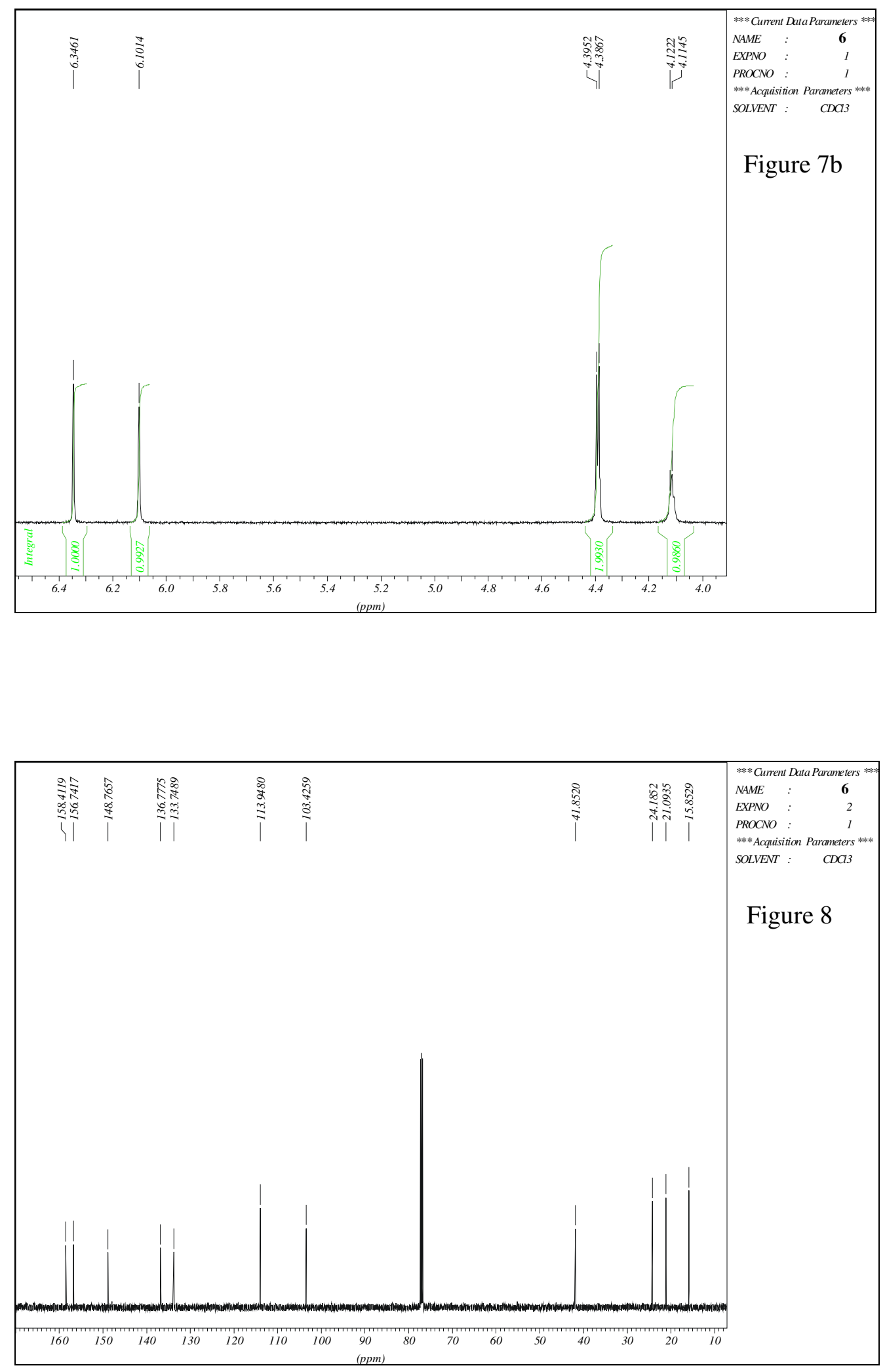
1,3,5-Tris[(4,6-dimethyl-pyridin-2-yl)aminomethyl]-2,4,6-triethyl-benzene (8)
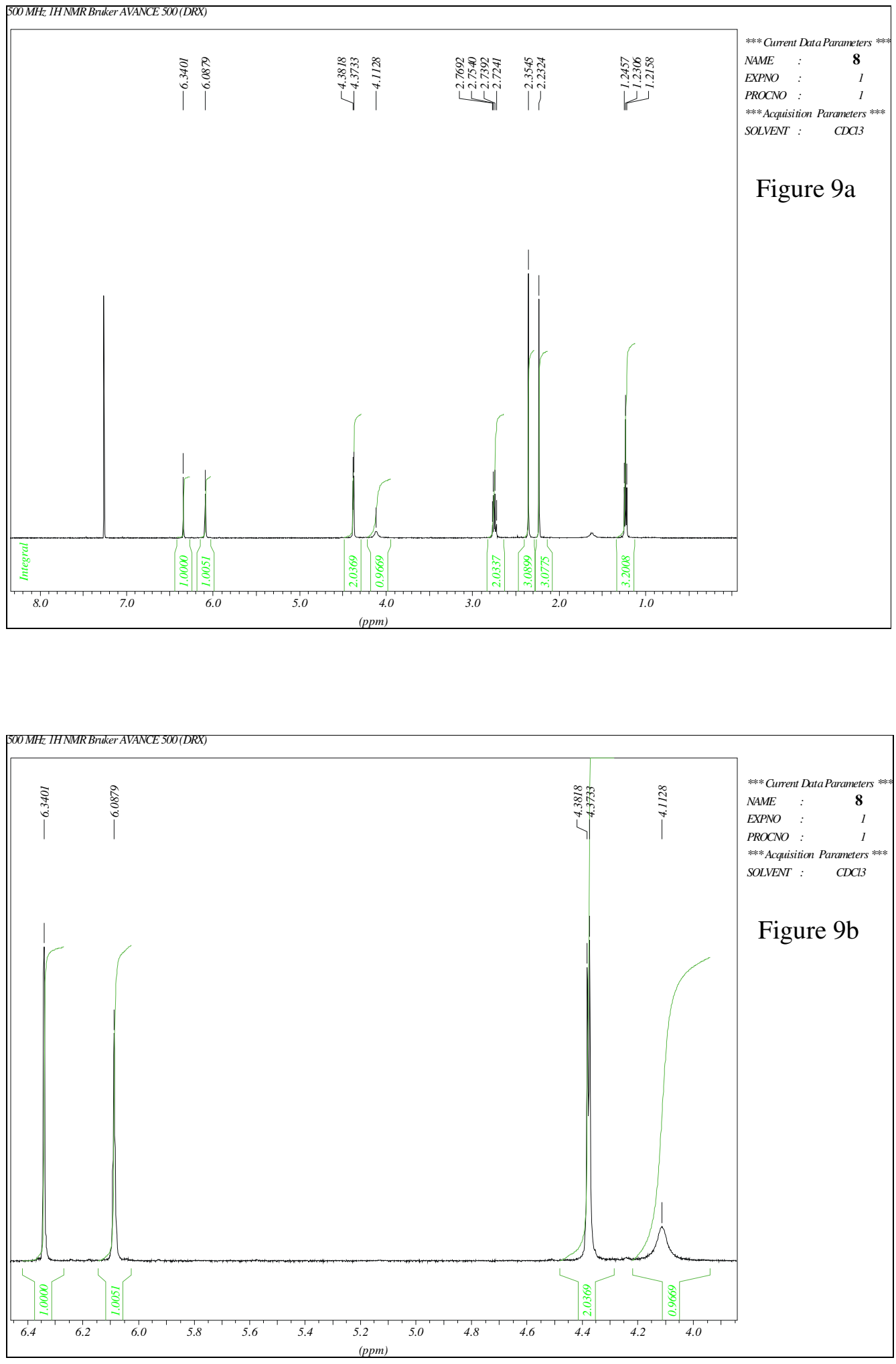


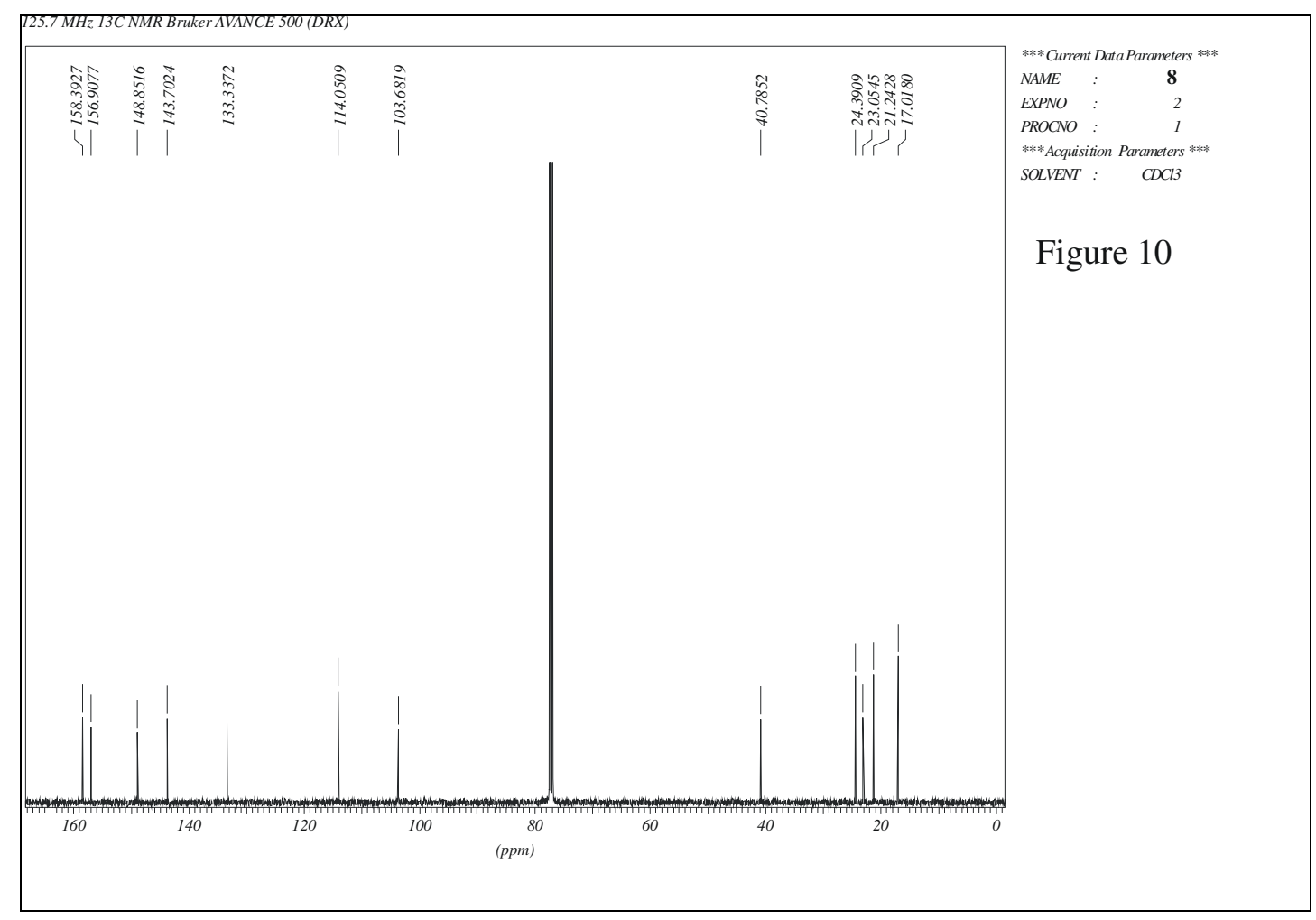

1,3,5-Tris[(6-amino-pyridin-2-yl)aminomethyl]-2,4,6-triethylbenzene (9)

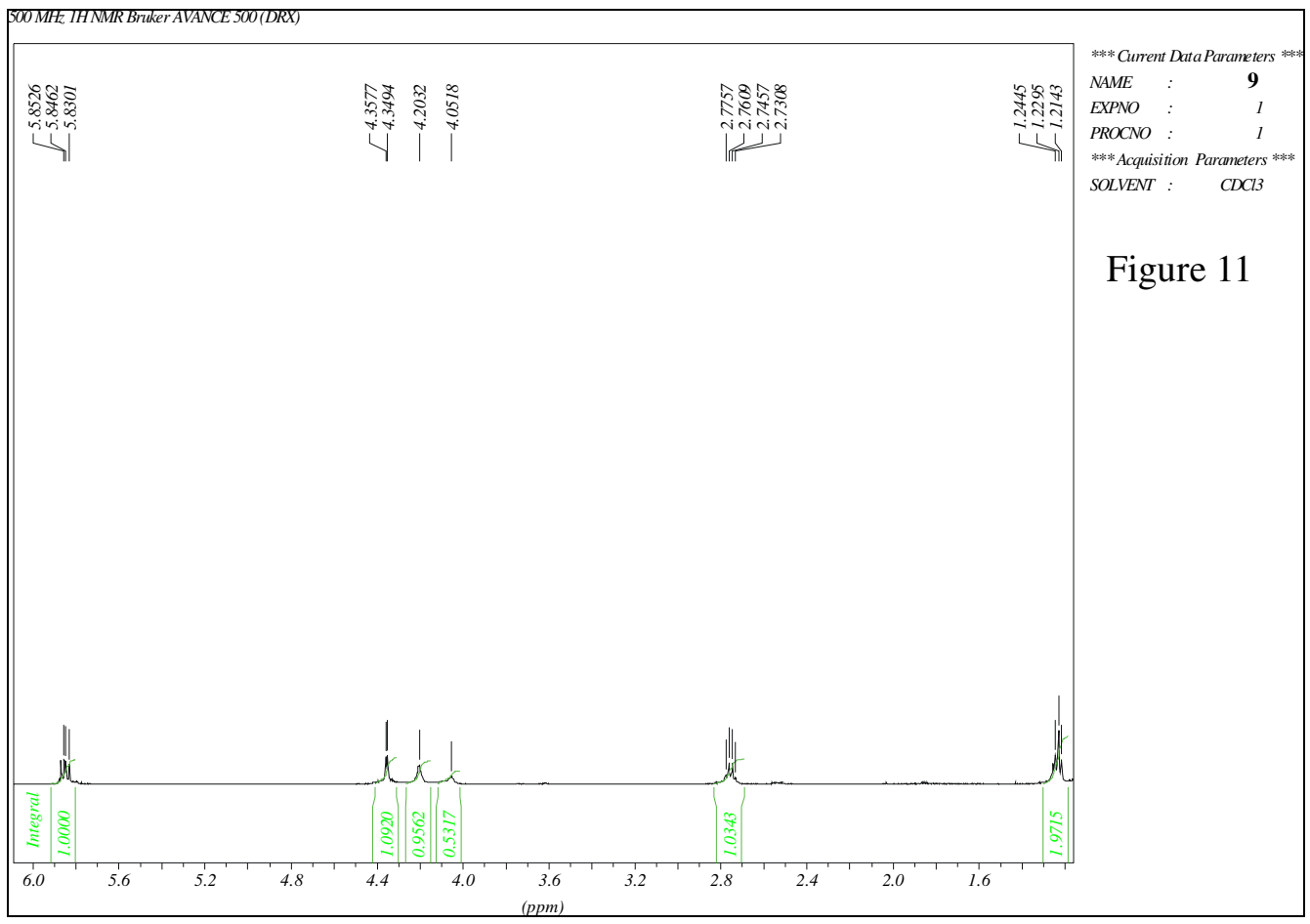




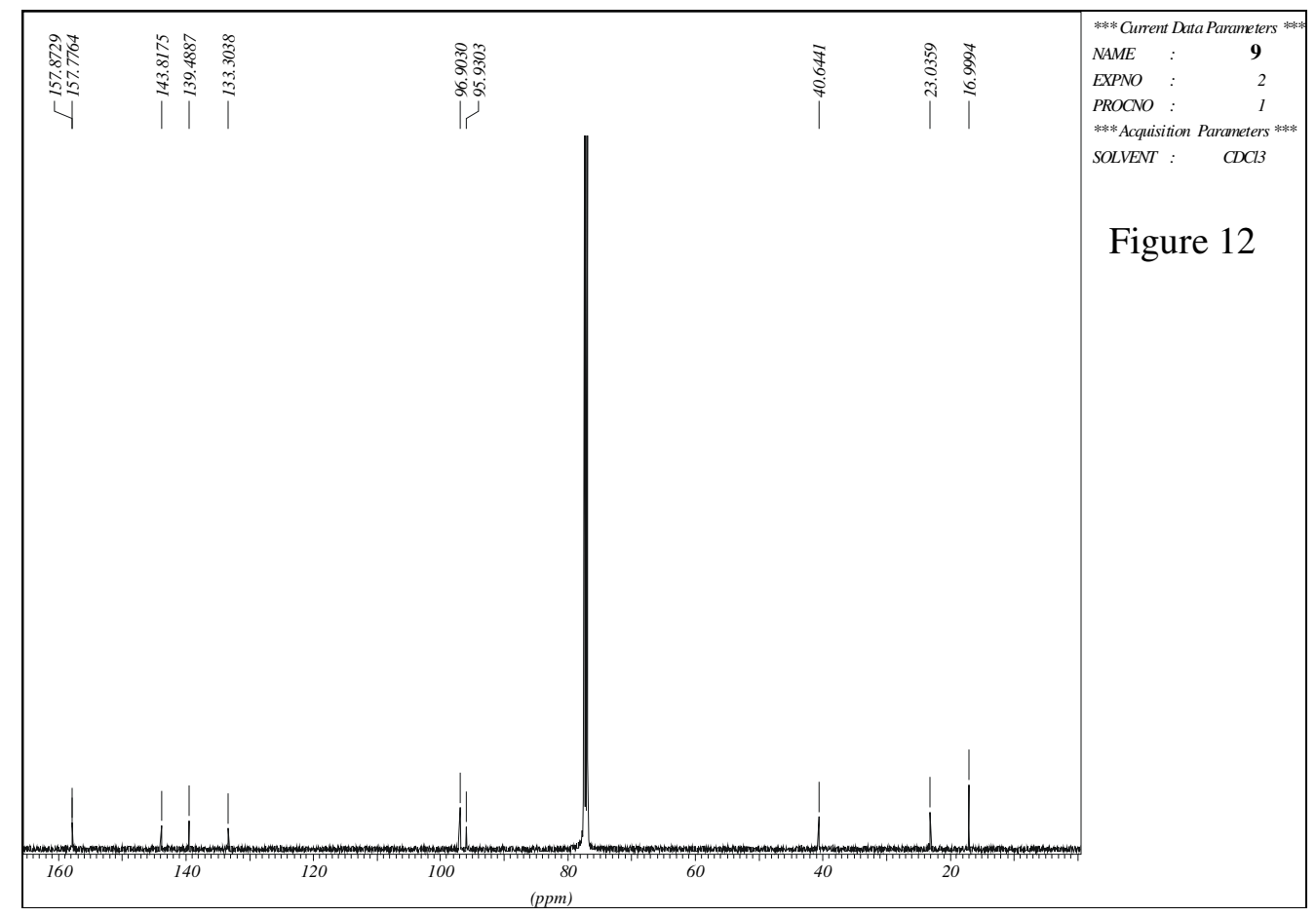

2-\{3,5-Bis[(4,6-dimethylpyridin-2-yl-carbamoyl)-methyl]-2,4,6-trimethyl-phenyl $\}-N-$ (4,6-dimethylpyridin-2-yl)-acetamide (10)

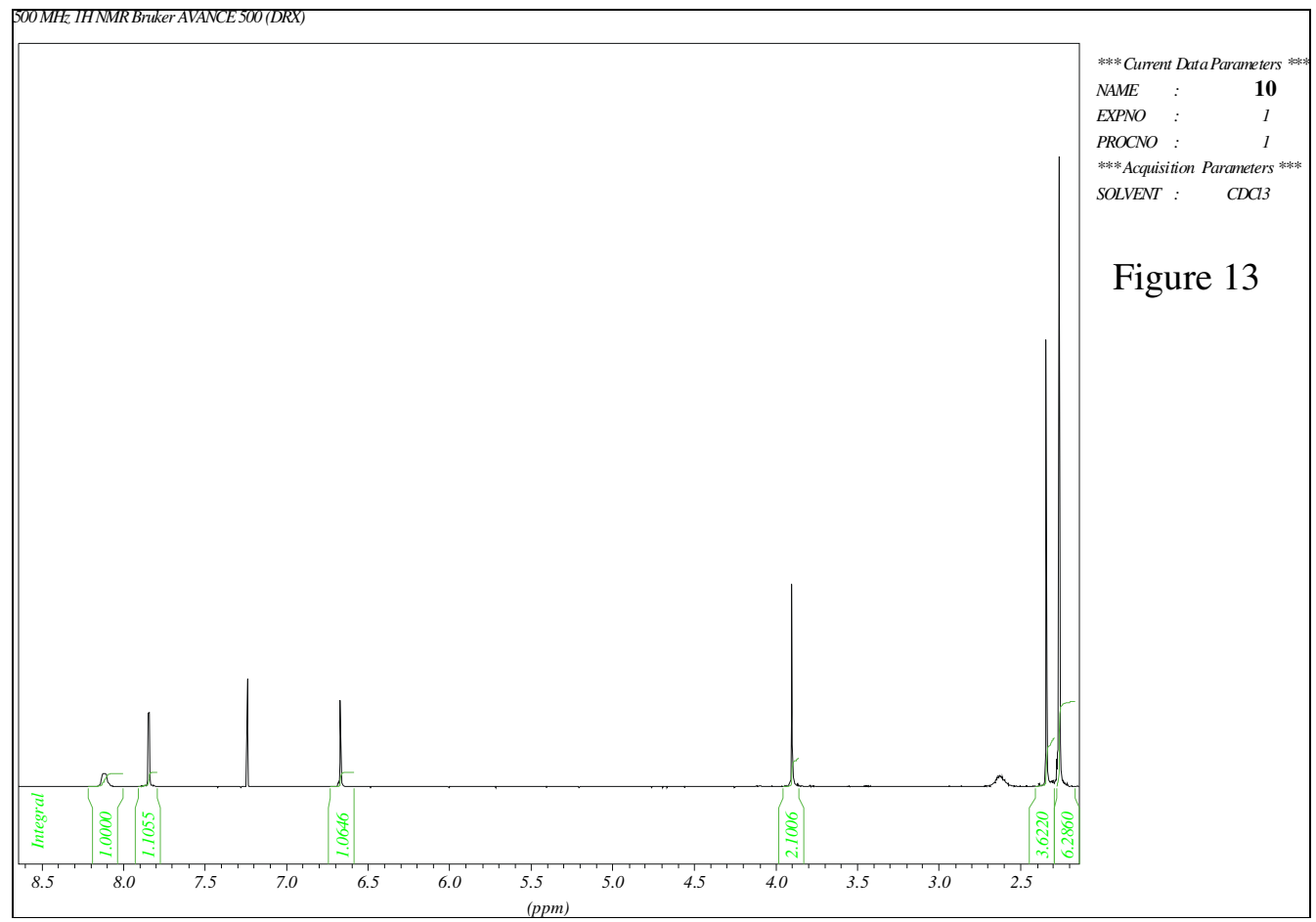




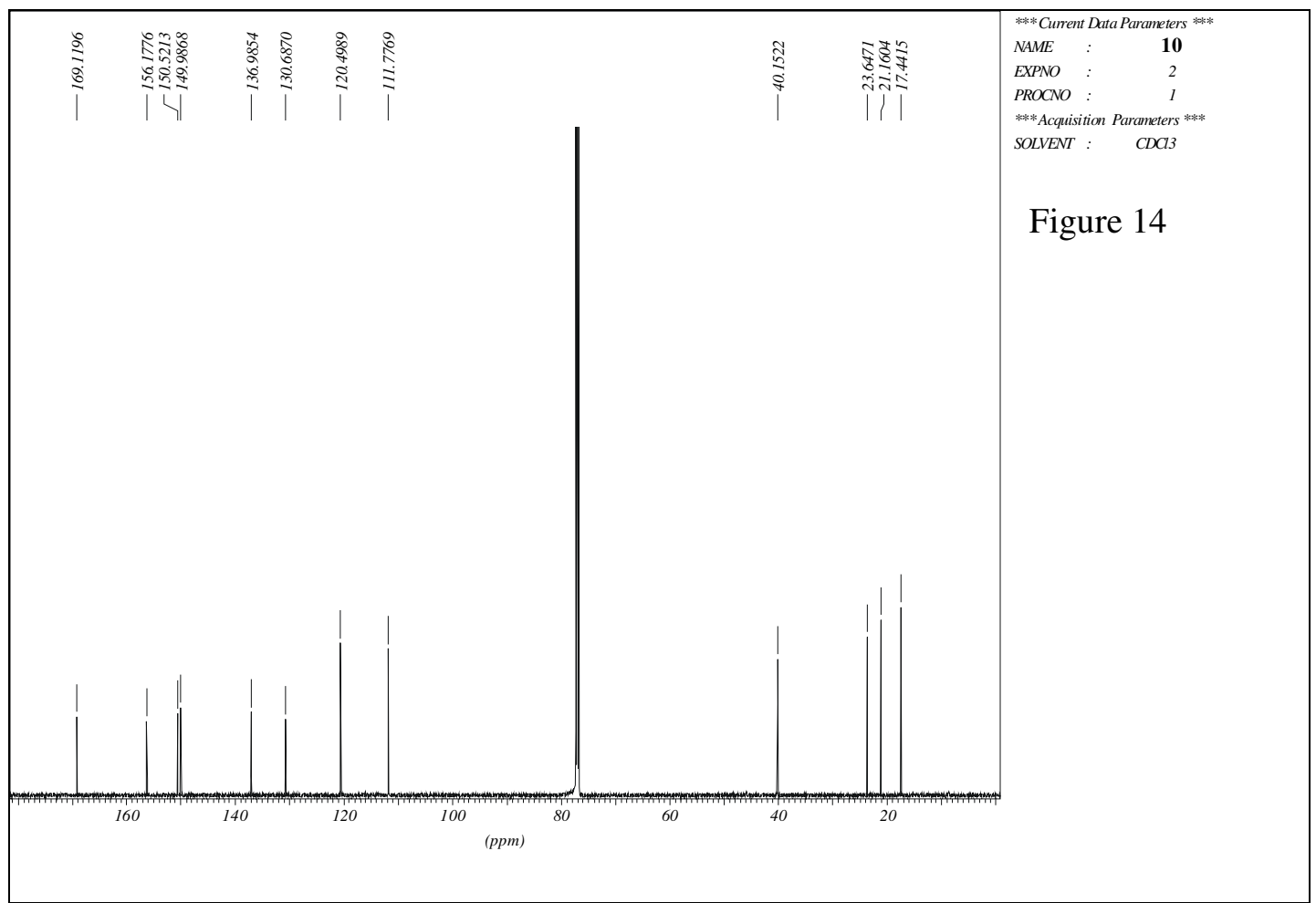

2-\{3,5-Bis[(4,6-dimethylpyridin-2-yl-carbamoyl)-methyl]-2,4,6-triethyl-phenyl $\}-N-(4,6-$ dimethylpyridin-2-yl)-acetamide (11)

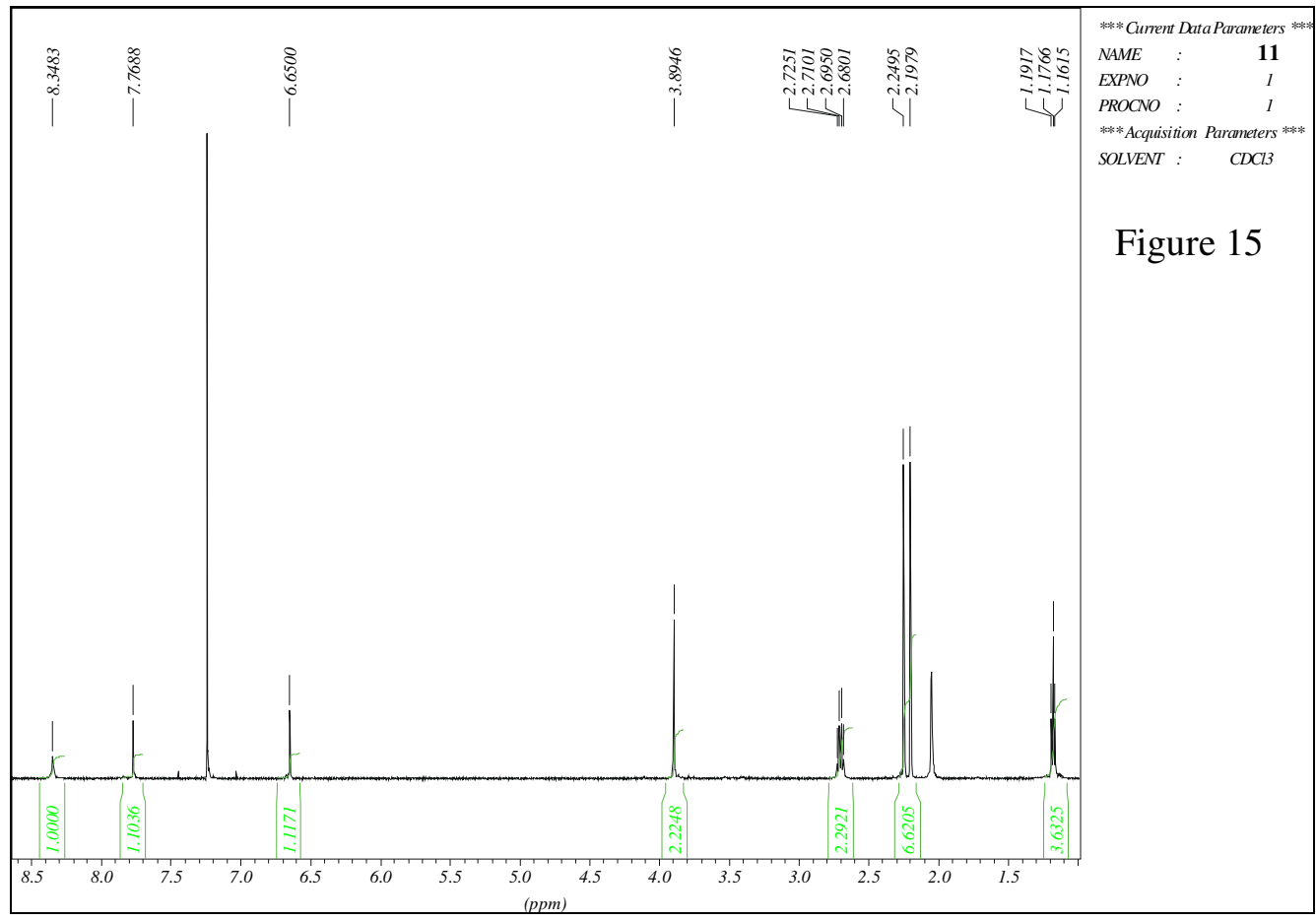




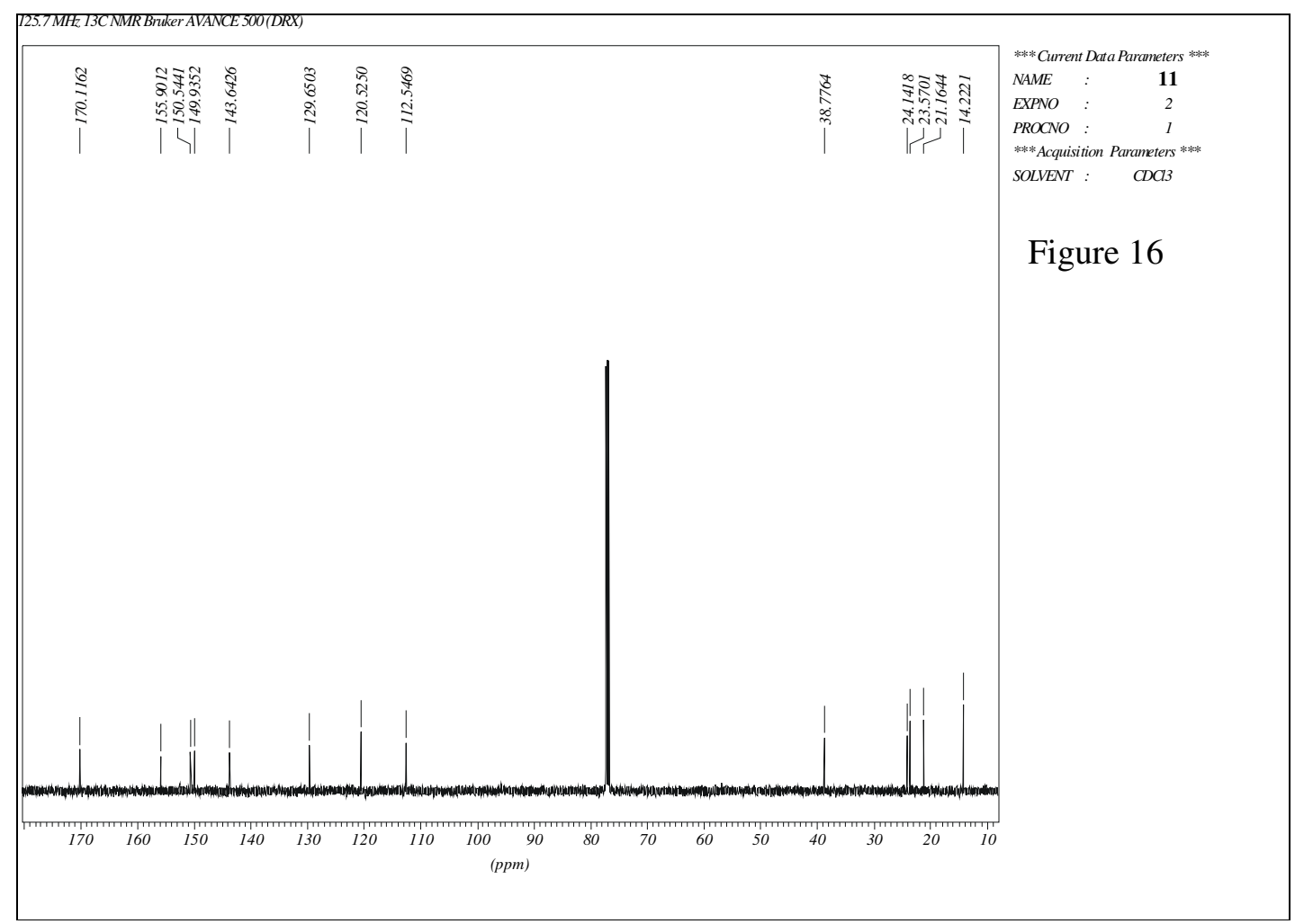

$N$-Di(ethoxycarbonylmethyl)- $N^{\prime}, N^{\prime \prime}$-bis(4,6-dimethyl-pyridin-2-yl)-benzene-1,3,5tricarbonamide (14)

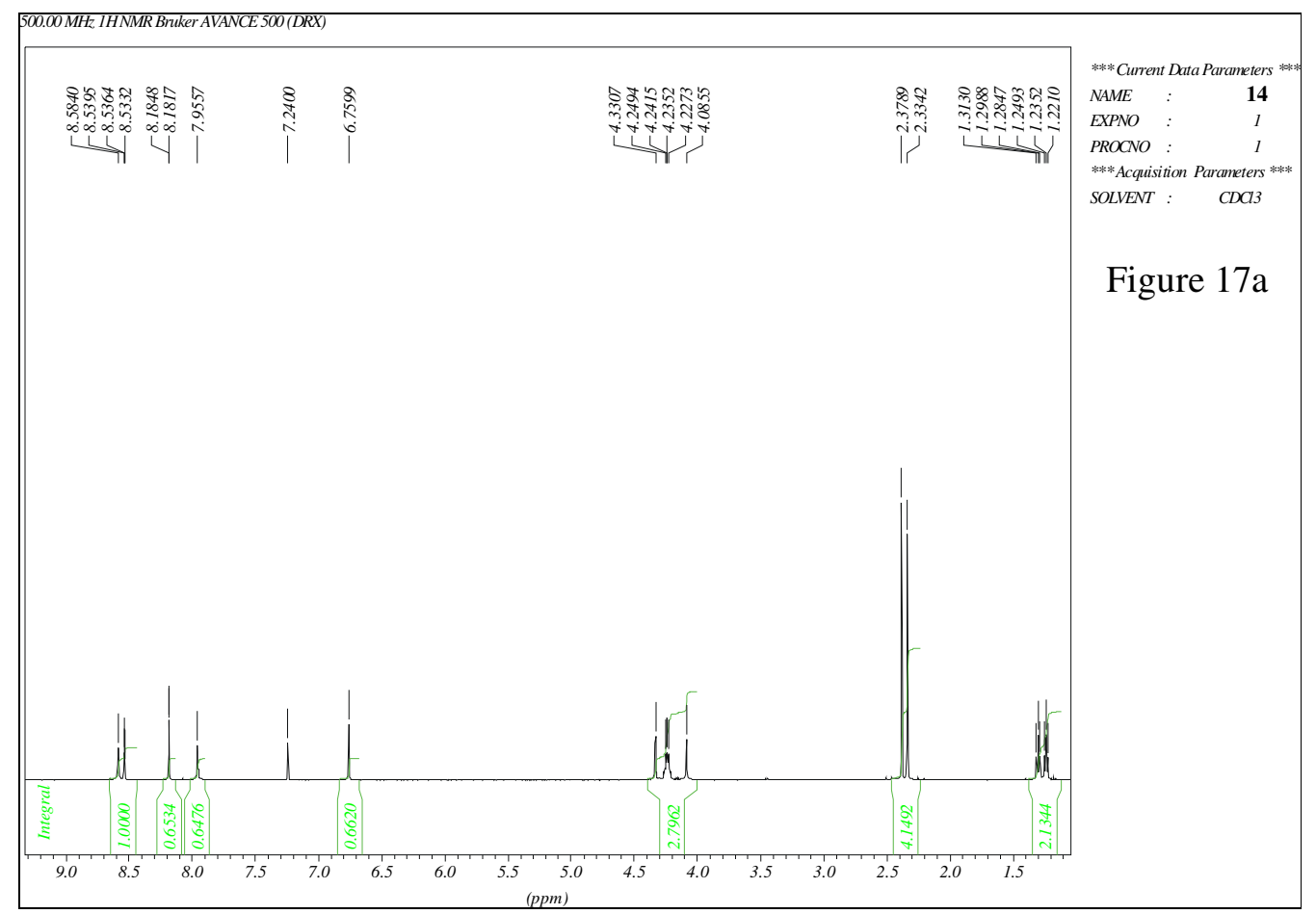



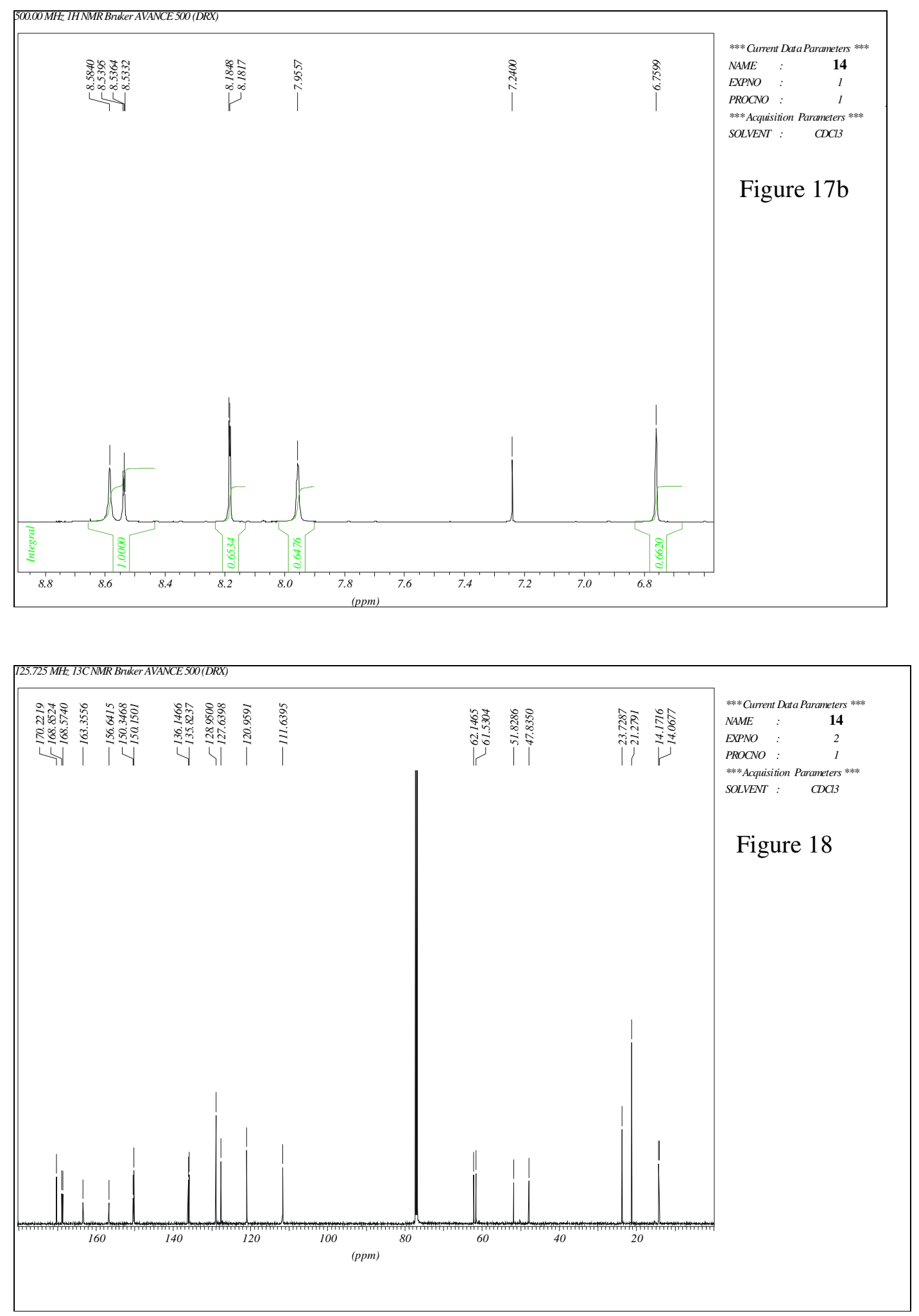


\section{$2 \quad{ }^{1}$ H NMR Titration: Titration of receptor 11 with $\beta$-glucopyranoside 16.}

a)

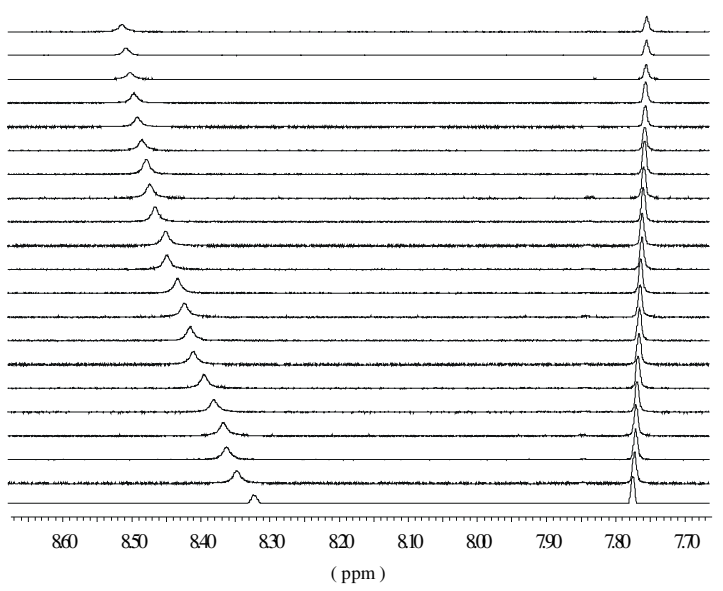

b)

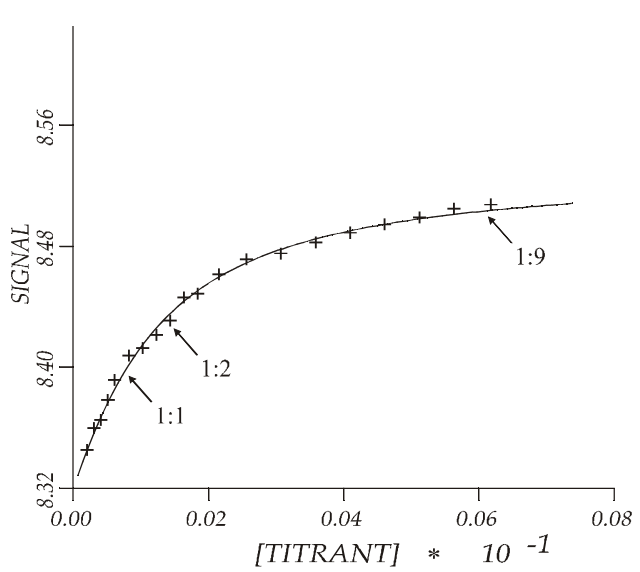

FIGURE 19. Titration of receptor $11(0.68 \mathrm{mM})$ with octyl $\beta$-D-glucopyranoside (16). a) ${ }^{1} \mathrm{H}$ NMR spectra $\left(\mathrm{CDCl}_{3}, 25^{\circ} \mathrm{C}\right)$ of the receptor $11\left(\mathrm{NH}\right.$ and $\mathrm{CH}_{\text {pyr }}$ resonances are shown) after addition of 0.00-9.05 (from bottom to top) equivalents of 16. b) Plot of the observed (x) and calculated (-) downfield chemical shifts of the $\delta_{\mathrm{N}-\mathrm{H}}$ resonances of $\mathbf{1 1}$ as a function of added 16. The [receptor]/[sugar] ratio is marked.

\section{$3 \quad$ Mole ratio method: Complexation of receptor 3 with $\alpha$-glucopyranoside 17 .}

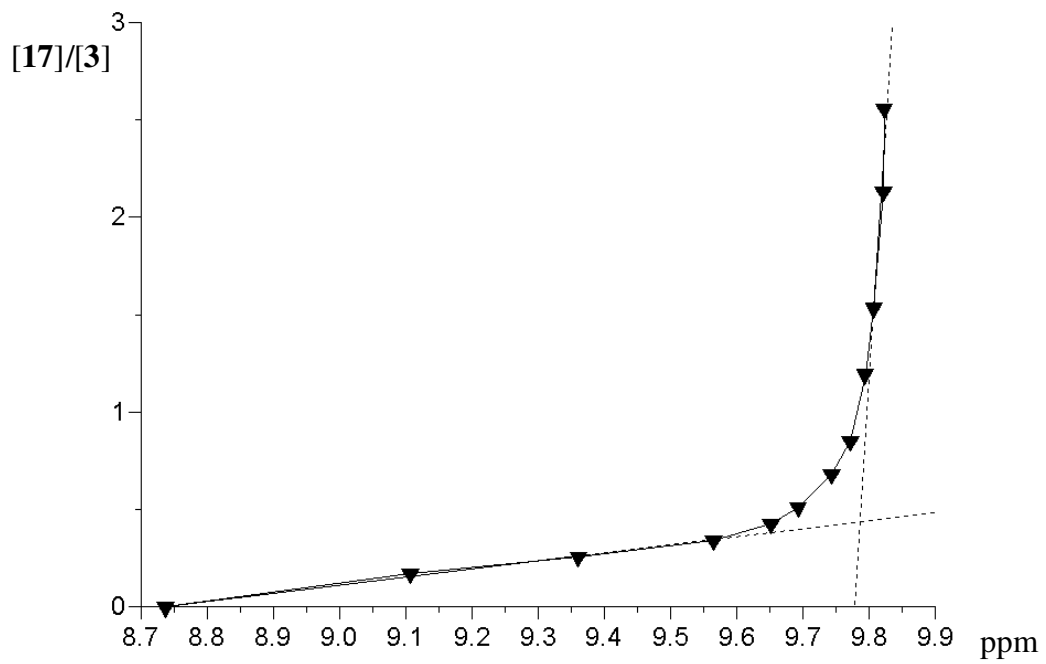

Abb. 20a: Mole ratio plot. Complexation of 3 with $\alpha$-glucopyranoside 17 (analysis of the shifts of the amide-NHs of $\mathbf{3}$; the [sugar]/[receptor] ratio is marked). 


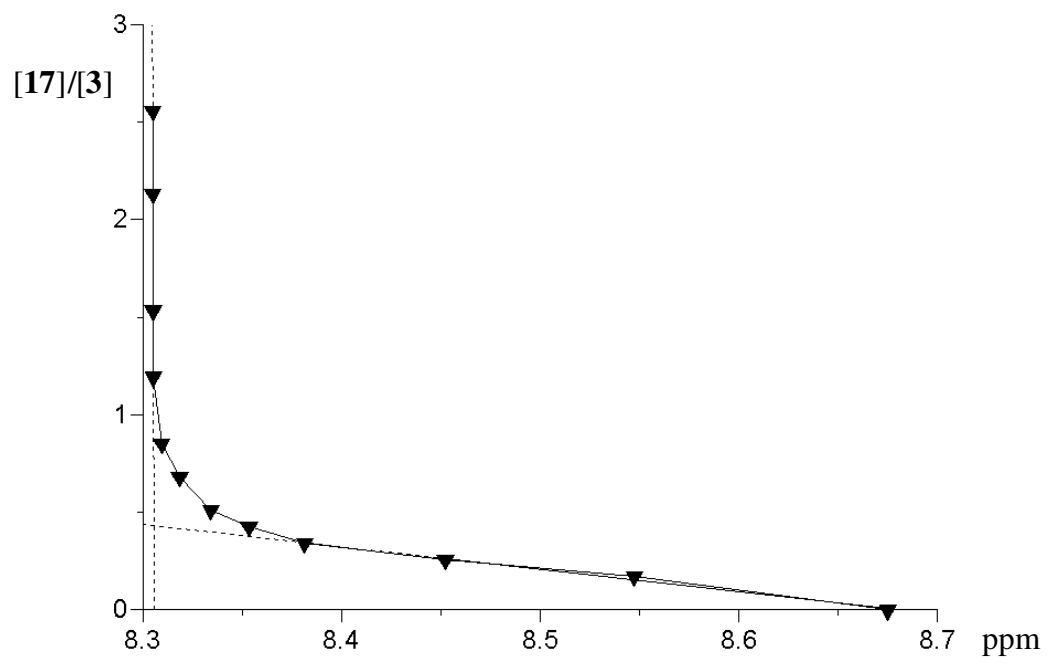

Abb. 20b: Mole ratio-Plot. Complexation of 3 with $\alpha$-glucopyranoside 17 (analysis of the shifts of the $\mathrm{CH}_{\mathrm{Ph}}$ of $\mathbf{3}$; the [sugar]/[receptor] ratio is marked). 